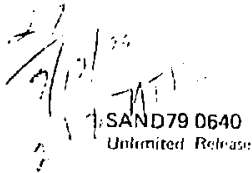

\title{
Waste Isolation Pilot Plant (WIPP) Borehole Plugging Program Description
} January 1, 1979

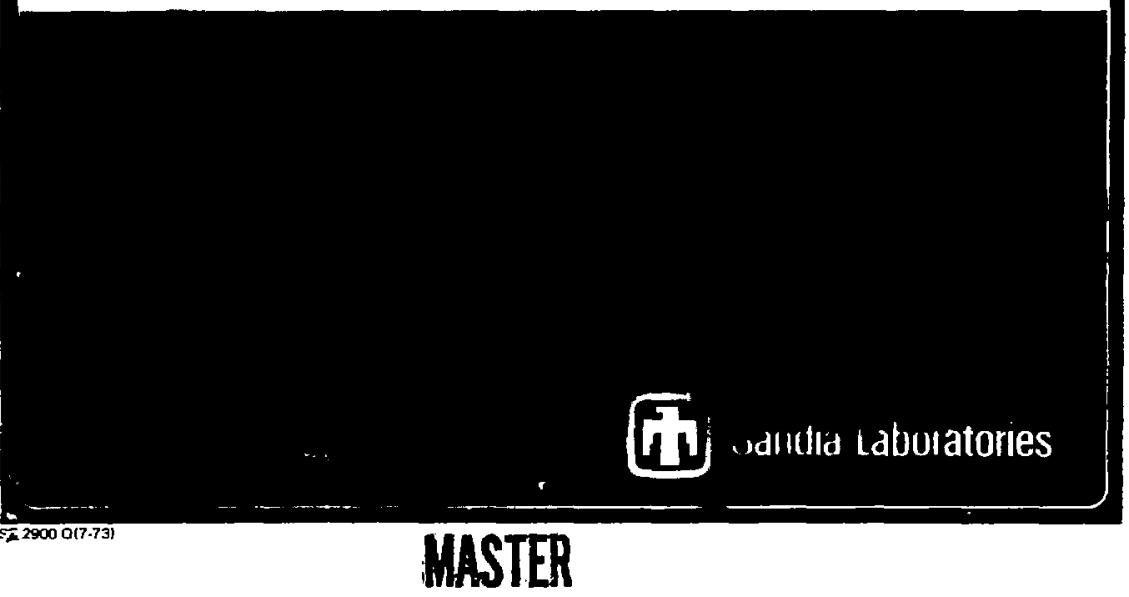




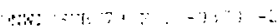

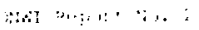

Uก! $1 \pi 1+\ldots 1 !+\div+1,4$

$\left.5 A_{1}: 1\right) 7 r_{3}-i q^{\prime}$.

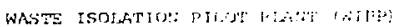

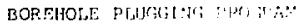

TREscon IPיIMN

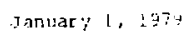

Prepared by

C. L. Che istenizen

T. 0 . Hunter

Experimental Programs Division 4512

Sandia iaboratoriss

Albuquerque, New Mexico 87185

Battel le/ONWI Subconteact iNo. E⿰LL L-03700

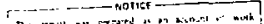

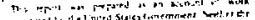

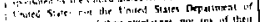

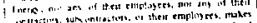

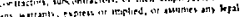

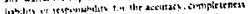

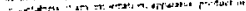
ancs tint

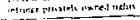




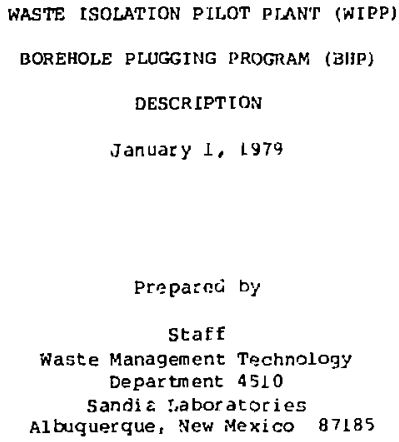

NOTICE

This report was prepared as an account of work sponsoced by the innited statpi Government. Neither the united States nor the Department of Energy, nor any of their employees, nor any of theit contractors, subontractors, or thei: employees, makes any warranty, expcess or implier, or assunes any legal liability or responsibility for the accuracy, conpleteness, or usiztulnes; of any information, apparatus, product, or process disclosed, or represents that its use would not infringe privately owned rights.

This report was prepared by Sandia Laboratories under Subcontract:

No. ESL1-03700 with Battelle Mernorial Institite, Project Management Dirision, under Contract EY-76-C-06-1830 with the Department of Energy. The subcontract. was administered by the office of Nuclear waste Isolation.

The assistance of Mr. Floyd Burns of ONWI and Dr. Robert s. Newton of D'Appolonia is acknowledged and appreciated. 


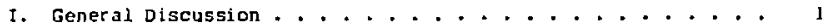

I. Objectives . . . . . . . . . . . . . . . . . . . . . . 4

III. Rationale for Plan Organization . . . . . . . . . . . . . 5

[V, Issueis to be Addressed . . . . . . . . . . . . . . . . 7

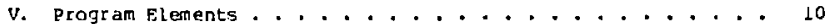

A. Quantitative Assessment of Current Technology . . . . . 10

B. Consequence Assessment . . . . . . . . . . . . . . . 10

C. Test Program ....................... 11

b. Enviroment Definition ............... 12

1. Media Quantification Experiment . . . . . . 13

2. Materials .. . . . . . . ., . . . . . , 14

1. Short Term: Current Technology

1. Grout Develoment and Plug/ Host Rock properties

2. Industrial Assistance

3. Plug Design

2. Long Term: Advanced Technology

1. Geochemical Program

2. Alternate Materials

3. Instrumentation. . . , . . . . . . , . . 18

1. Short-Term Needs

1. Enviconment

2. Plug Assessment

3. Labor atory

4. Miscallaneous Concerns

2. Long-Term Needs

4. Eield Test Matrix .................. . 22

1. Curcent Technology Well Bore Tests... . . . 23

1. Bell Canyon Test (BCT) .......... 23

2. Shallow Hole Test (SHT) ......... 27

3. Diagnostic Test bole (DTA) ....... 30

2. Potential Technology In Mine Tests... . . . 33

1. Salt Plug Experiment.......... 34

2. Advanced Instrumentation........ 35 Development (AID)

D. Sumary . . . . . . . . . . . . . . . . 35

VI. Quality Assurance .. . . . . . . . . . . . . . 36 
TABLE OF CONTENTS (ContinLed)

\section{$\underline{\text { PAGE }}$}

Ht schedules . . . . . . . . . . . . . . 39

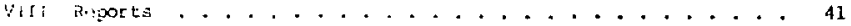

tK o:ganization.................... 42

APPENIJIX

A. References . . . . . . . . . . . . . . . . . 44

B. Bibliography . . . . . . . . . . . . . . . . . . . . 45

C. Genlogiz stratigraphy thear wrpp sice.......... . 47 
LIST OF FIGURES

\section{FIGURE}

PAGE

$1 \quad$ Bell Canyon Test (BCT) Schematic 24

2 Shallow Hole Test (SHT) Schematic 28

3 Diagnostic Test Hole (DIF) Schematic 31

4 Borehole Plugging Program Logic Diagram 37

5 Proposed WIPP Borehole Plugging OA Organization 39

6 Proposed Reports and Program Schedule 39

7 Proposed Test schedule 40

LIST OF TABLES

I. Potentially Significant Issues 9

II. Near-Term Instrumentation Availability 20 
WIPP BOREHOLE PLUGGING PROGRAM DESCRIPIION

I. General Discussion

Decommissioning of waste reposicories will requice cejsonable assurance that public health and safety will not be affected during or subsoguret to such actions. Inherently this implies that the emplaced wastes will not be expected to reach the biosphere, given realistic and rational release scenarios, in quantities that represent a health hazard to thr human population. To expect absolute assurance that no radioactivity will over reach the biosphere is unreasonable; to expect that all reasnnable preraution:s will be taken to minimize the celease to accepted safe lovels should by a requicerent Eor Jecommissioning of the repositiory. The borchole plug.jing program herein kescribed is one facet of the latter equirement.

Preventing release of waste radionuclides via man-made penetrations is tha basic premise for the borehole plugging progran which, in turn, requices that. fluid migration into and out of the repository be minimizer and controlled. Thus the overall effort is directed at the understanding and control of: liluid circulation near the plug. The requirements for a successful solution invalue: the Eollowing considerations:

\footnotetext{
For a man-made penetration into a repository formation, what is the potential for and consequence of waste egress via this pathway; in what. manner bes the penetration compromise the integrity of the formation a.s? for what duration?
}

Clearly, this is a complicated, difficult guestion which is site spect $t_{15}$ and cannot have an absolute univecsal answer. This program will address the issues involved for WIPP and attempt to quantiEy plugging techniques that protect the public interest and safety.

The salient issues in the above question are:

1. What is the potential for egress?

2. Bow is the formation integrity compromised?

3. For what duration is the formation integrity conpronised?

4. What is the consequence of egress? 
The wije BHP Program will attempt to provide answers to each of the above issues and will be site specific to the proposed southeastern New Mexico (SENM) WIPP site. Extrapolation of results to other geologlc strata must be done carefully and thoughteuliy.

1. The potential for egress depends on many factors. For purposes of the BHP program, the assumption is that, in the long term, some radionuclides will be in a lecation (i,e., at a borehole/media interfacel to be transported via salution in brine either through the plug material, the formation rock near the plug/media interface, or along the interface itself. The issue here then is to address techniques for the Following:

A. Minimization of Eluid presence at the waste horizon.

B. Determination of Elow rates under the assumption that $f$ luids have reachea these horizons through the well-bore.

C. Control of possible gas releases.

D. Determination of leach and transport $r$ ates of radionuclides at the det irmined Flow rates.

2. The effect of a well-bore on formation integrity cepresents the major thrust of this progran since the capability to preclude egress depends directly on how closely the formation was restored to its undisturbed state. The determination of the Eormation material propecties prior to well-bore introduction, and the restoration of these properties are the prinary goals to be achieved in the BHP. The issues tc be addressed are as Eollows:

A. What are the undisturbed media tiluid migration rates ans pathways?

B. How do migration rates and paths through and around plugged well bores compare to the natural values?

C. Can the well bore migration rates be made comparable to or less than the natural rates, and what is the impact of possible unresolvable aifferences? 
1). What are the consequencez to public health and safety for:

1. natural migration rates?

2. achicrable well boce tates?

3. Pta Malitity geriod for the established well-bore rates is a more ditlicut issue. clearly real-time proof over geologic lifetimes mannot be demonstrated, bit geochemical techniques may be used to demonjt:ate long-term stahility of plug materials in a given myitonacht and theso techniques will be utilized and expanded in an ongsiog NiPP progran to assess the long-torm issues for WIPp and to provise a technology basis for the multi-nedia, muIti-bartier Generic borshle Plugging Program being dicected by the office of Nuclear $\because$ arto Tsolation (OHWl).

4. Tive conseguence of egress to the biosphere must consider the tiac depantert nature of the nucides, migration time and mechanism to and through a well-bore parhway, sorption/desorption mechanisms during trangport and, Einally, the decayed nuclide source strength and method of introduction into the ecosystem upon arrival at the biosphere. whis problem is being addressed in the risk and consequence analysis portion of the sandia WIPP program. For the BHP program, it is sufficient to evaluate whether fluid ingress and subseguent egress : hrough the trell-bore pathway is easiec or more dieficult than through the native naterial pathwy on the basis of criteria received fran the inIPP Conisequence Analysiz Program. There are indicarions *om the WIPP consequence Analysis Progran that even the worst case of an unplugged well bore does not represent a significant impact on the public wall-being. Further efforts to better quantify this consequence will continue concurcently with the BHP program. 


\section{Objectives}

The preceding discussion leads to the formulation of the following objectives to be addressed in the WIPP BHP program.

- Assess impact of leakage through man-made penetrations reiütive to natural migration pathways by determining potential effects on public health and safety utilizing consequence analysis and site specific data to specify acceptable well bore leakage critera.

- Develop materials, techniques and instrumentation to determine the adequacy of plug designs in keeping well bore leakage conparable to that along natural migration pathways.

- Use geochemical cechniques to evaluate long-term plug design arieguacy.

- Evaluate impact of plug failure at various lifetimes with corresponding consequence analysis.

a Provide acceptable plug design and installation rocedures as the final product for application to the GIPP, including evalustion and developnent of a multi-layered, multi-purpose plug design. 


\section{IIT. Rationale For PIan organization}

The overall plan developed here is the result of workshop neetings, private conments, published critiques, anc the wIPp schedule. $A$ general overview of the why's and how's leadinr to the plan is presanted here.

commencenent of WIPP construction may include a equirement chat a BHP tecinology program is underway and that favorable cesults can be oxpected to isolate the repositor $y$ when the futuce decomissioning date is reachers. Ni:": construction scheduled to begin early in 1981, results must be whtained in 1 ine short term to support the feasibility of isolating the repository. To meal: this initial requiremcnt, cenent-type materials will be used in the ismeriare program since this technology is already well estabij.shed and there are w fundamental reasons to suggest that cementitious materials will not be: adequate for the long term; however, this is not to pieclude the use Ji alternate materials both for the olug itsele or as an interlayered attenuaring (sorptive) material in the long term. Subsequent develogment of the piograr

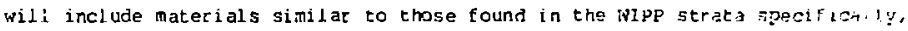
incluöin! muti-layer, muti-purpose plug designs.

While the use of natural materiais may seem more satisfying iq porintting restoration of the media with the least possible discontinutil and while sors: initial Laboratory results are encouraging (Martin (975), field demonetration techriques have not been adequately developed. Therefore, paral al paring for the long-term analysis of plug materials will be taken, one addressing the identification and use of natural plug materials, their emplacenent and adequacy, and one addressing the long-term geochemical stability and suitability of grouts. In this way, the long-tem stability of grout, if demonstrable, would provide a solution or at least a choice of techrique: ror the long term.

Thus, the program development evolves into two basic activity time Frame:; (1) short-term efforts, involving current technology, and (2) identification and development of long-term efforts invalving potential technology. For clarity these are arjitcarily defined as follows, recognizing that freaist? time delineations are neither possible nor requited. 
Short term: $1-2$ years (s.9., to 1980) real time in whych effectg valio for $10-60$ yoars can be predicted.

Long term: 2-30 years (o.g., to 2000) real time in which it may be possisl $=$ to predict effects valid Eor geologic times.

The inital chrust of the program will be to explait the short-term issuan with the immediate goal of satiefying wipp construction schedule requirements. and fyolving inte a definition and alution leading to the satjsfaction of the ing-tarm lasues.

The peinary test beds will be well bores, nominally 6-8" in diameter in which emplacement and testing techniques will be developed with subsequent adaptation to shafts with diampters en the order of fert. A fundanental issure to he arsessed is the extent of the disturbed zone in the proximity of the weil-bore or shatt vall and how this is afected by the technique utilized in cceating this wall bote, i.e., drilling, coring, or blastitig, and the subseguent effect on approptiate plugging efforts. Specific attention will be given to the influence of these effects on methors used to constuct the wiPP cepositor $y$. 


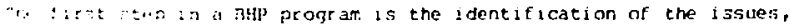

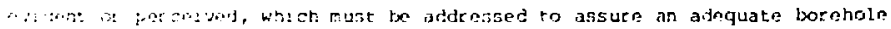

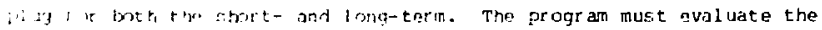
liserta

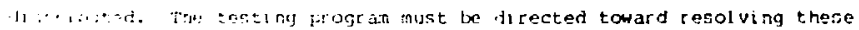

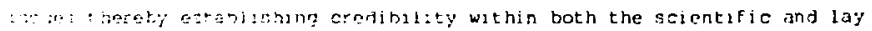

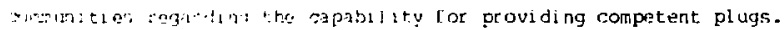

is rata: a $\because$ ramary of potentially important issues (without consideration

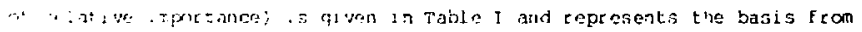

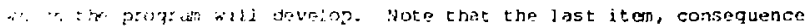

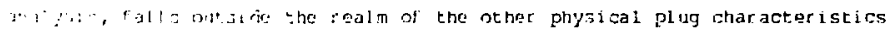

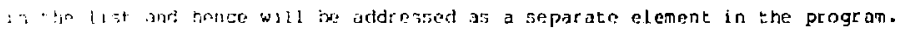

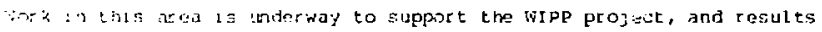

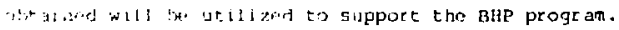

Q11 of thess 1 ssup!s will be addressed to assure that the phasing of abjacoz $y$ and Liela prograns is appropriate to support a schedule rutman:surate with WIPP progran needs.

To acconist 1 in the objectivez of the progran, specieic delegation of tagks nut bs dons to insurn a coordinated effort. The general assignent of these torks is as foil xwis:

1. Quantitative Assessment of Current Technologx: Formal collection of axisting tochnology data will be done by ONWI suhcontractors.

2. Conseguence Analysis: Size spociflc data will be provided by Sandia Ior I ntegration into the AIPP consequence assessment progran and for determination of acceptable migration rates. Sandia consequence analysis will be coordinated with WISAP studies as appropriate.

3. Materials: Grout recipes will be developed and distributed by Sandia. Laboratory resting will be done as a joint effort between Sandia and ONWI. The geochemical program will be initiated by oNwI with sitpport from Sandia. The alternate materials progran will be 
developed by ONWI with field test becis proulded by sandia. Specific plug design will be a sandia effort with calculations coordinated with any onw contractora. Grout recipes ani plug seepage criteria will be provided by Sandia.

5. Instrumentation: Requitements and development will be accompl isted by Sandia.

6. Fleld Testing: Requirements will be provided by Sandia

7. Quality Assurance: Plan developnent and implementation will bo a joint effort between sandia and oNw. . 


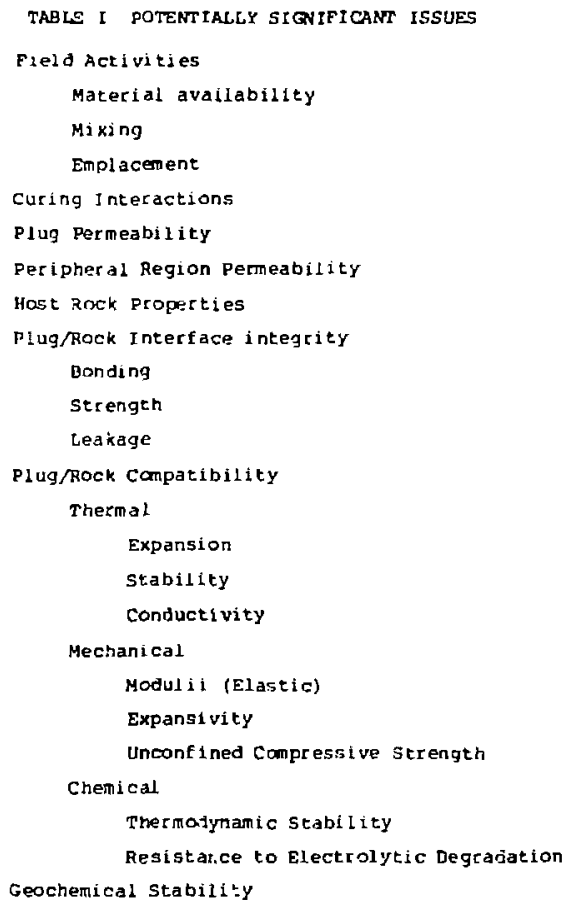




\section{v. PROGRAM ELEMENTS}

At nur present state of knowledge, sevaral progrem elements have been i dentified tor which activity is required. These elements include activities which are fortinent to both hIPP speciflc concerns as well as more generic siudies tor BHP. The appropriale responsiblities for some of these activit!ss will be resolved ats the hIPP BHP program is integrated into the oNw generic program [or BHP.

\section{A. Quintitative Assessment of Current Technology}

In addition to survers and : mumarization of all pertinent efforts in BHP, a concarted effort will be made to quantify and document the related industry and DOF efforts at borehole plugging. These include data fran gas storage Cields, in-situ permeability tests, etc. Emphasis should be placed on determining how eflective the methods are and organizing thn data into a presentable form so that its applicability to nuclear waste repositories is apparent. Useful historical data may be gained from plugs which have becn emplaced for long enough times to infer information about pluq behavior.

Specifically, additional information may be obtained by analyzing plugged boreholes used for potash exploration near the wIPP site. These holes were plugged and subsequently intercepted as mines were developed. since numerous holes are typicaily requized for ore horizon definition, good statistics may be available on plug integrity and plug adequacy provided by the emplacing time technology, permitting updating and comparison to now curzent cementing techniques. Information contained in the "status Repnrt" on curcent rechnology presently belng prepared for owf will be the basis for this program element.

\section{B. Consgguence Assessment}

Development of analytic consequence assessment codes to address the results of water $E l$ in in boreholes or gas migration out of the repository will be valuable in determining what is meant by an "adequate" plug. Preliminary work in this area for the HIPP specific enviroment would indicate that an absolute seal is not required (Brannen, 1978). Moreover, even the most conservative assumptions about establisment of direct flow between the Rustler aguifers (Appendik C, Figure C3) and the disposal hor izon does not 
Lmi. $=0$ cadimuclide concentrations at potential discharge points which exceed it: r. raxing permissible concentration standards. The goal should be to U1 1 ze ounegurno analysis to determine acceptable leakaze criteria and to Jr.vi a plug to meet this criteria. Then the added protection of the plug

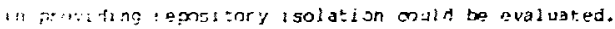

; p. priste yariation on the concept of the bornhole plug is to fr. li, un uly causn it to be more permeable than the native rock, thus

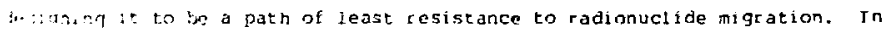
i: wi, : ong-errir ranionuctide migration tesuleing from the possibie

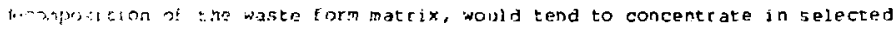
wi: Wr: pul misys from which samples could be taken and the effective

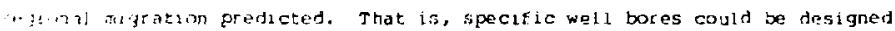
$\because: 4, y$; weat : ink, a fuse ai it were, which would provide early-time

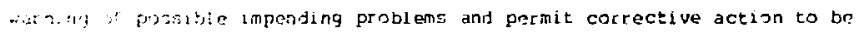
- Arim i: requiret. A mnsequence analysis model of this scenario should be $\therefore$ : in the nvarall consaguence ansesment. Additinnal work incorporating

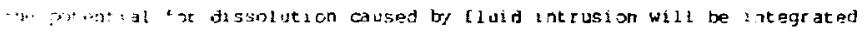
(1)', thase arsessmerits.

Jonilasions : rom the consequence assessment at the wiPP site may not,

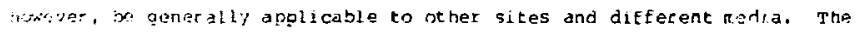
loxi: nydrologis environment and nuclide migration potential mus: be ganidered bof ore similar conciusions are made for other poteritiat.

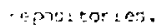

\section{$\because \quad$ Test Program}

A general tosting progran will be implemented based on the integration of : a. fat iaboratory programs. The principal initial activities will be ritrcturi toward determining which of the issues in Table $\tau$ are in fact sagni icant and on the application of curcent technology (cementitious grouts and annontional/near-term instrumentation) to boreholes near the wIPP site.

?midite drill holes will be selected from:

] industry hales near the WIPP site,

o previousiy drilled wipp holes,

o new drill holes, if necessary. 
Holes within the HIPR site will not be uged in the testing progran. Extension of the test program to long-term issues will froceed as the progran avolves and is discussed in each subsection.

The thr ust of the program will be to form a suitable mix of calculational modeling based on stte-specific data, laboratory testing of appropriate grouts leading to a plug design, supportlve instrumentation developnent, and plug emplacement field testing and experiments utilizing available techniques to provide a credible data base to support the borehole plugging technology.

These concepts are expanded in the following sections.

\section{c.2. Envizonment Definition}

Determination of the plug enviromment wilt be requiced to permit development of the plig design models and realistlc consequence analysis scenarios. Site specific data must be obtained as the $\mathrm{E} i \mathrm{rst}$ step in this process, and the various items of interest include:

Hole conditions - This requires characterization and decumentation of yal $\mathrm{l}$ surface conditions, and the degree and exrent of disturbance caused by drilling or stress relief. These data will be provided by extensive logging of potential holes. It will be sufficient to utillze state-of-the-art logging techniques to make a satisfactory assessment. Any special hole treatment or preparation necossary before plug emplacement will depend on this evaluation and become a part of the plugging guality assurance procedures.

Host Rock Properties - The host rock also will be characterized in terms of permeability, thermo/mechanical properties, and geochenical properties. In addition, it may be desicable to develop techniques to determine the local in situ stress state so that plug emplacement will not hydrofracture the borenole wall. Well bore core samples will be gathered whenever needed. 
A supporting experiment is:

Media Quantification Experiment - a dedicated area in a potash mine where facilities $w i 1 l$ be provided for investigations including the determination of in-situ permeability. local stress states, and chemical and thermal reactions between the media and the plug. These parameters can be investigated over a larger range not possible in a well bore. The resulting data will be used to cal ibrate ano jurge tihi" adequacy of similar daca obtained from borehales.

\section{C.1.1. Media Quantification Experiment (MQE)}

\section{Objectives:}

To evaluate piug/media interactions not practical in decp vertira: boceholes

Test Bed:

A dodicated location in existing mine workings.

\section{Rationale:}

Determination of media properties: within a borehole is inherentiy more difficult than in a dedicated region in a mine, and this experiment is raquired to support, supplement and calibrate those efforts whirh cannot be carried out within the borehole.

\section{Discusston:}

Knowledge of media parameters is an "mportant Eacet in intaroreting borehole test results. In many casts, sufficient data may not be obtainable from deep boreholes. Sone anticipated studies in the mine include media pecmeability in situ, calibration of developmenta: instrmentation, in situ stress measurements, definition of Ecacture region and healing around boreholes, and depth to surface Eluid and gas migretion paths and $r$ ates. Sandia is currently negotigting fur a dedicated expertment area in a mine to conduct WIPp related investiga$t i$ ons and space within this arfa would be avallable for the MQE. Sandia has also developed a permeabillty progran in support of the WIPP which will provide helpful data to be integrated into the BHP program.

Schedu 1e:

sane Impact. A dedisated area is in the negotiation stage and impiementation of the in-mine experiments ace contingent on the outcome of these negotiations. 


\section{C.2. Materials}

The materials portion of the Borehole Plugging Program encompasses both shot - and long-term asperts of materials resear ch. This involves both iaboratory and supporting field efforts for the near term and an initial laboratory develoment effort for the long rerm. These aspects are:

J Shore Term: Currene Technology

Grout develoment and analysis of plug/host rock properties Industrial assistance

Plug design

- Long Terin: Advanced Tecnnology

Geochemical program

Alternate materials

\section{C.2.1. Short Term: Current Technology}

1. Grout Devolooment and Plug/Host Rock Properties

For the short-term goals, these iterns are being addressad specif ically by the Haterways Experiment Station (NES) at Vicksburg, M1, under Sandia sponsorship (Gulick 1978). Specific tasks demanded by the aHP progran will be phased into the ongoing research program as required by the field-test program. Additional support from other laboratories will be requested through ONWI as necessary. The following list of tasks is underway or planned in the aEs program along with the supportive field efforts:

(a) Continued evaluation of all candldate grout specimens whlch are included in long-term exposure tests, samples of lab-development mixtures and field samples, as weli as cores Erom ERDA 10 field plugging operation. Nondestructive testing methods such as measurenent of weight change, scnic velocity, and dynamic modulus of elasticity are the prime techniques in these evaluations.

(b) Testing and evaluation of cements, Dozalans, (flyash), expansive additives and admixtures to determine properties and imptove grout mi hiures.

(c) Permeability studies of grout samples, particularly grout/rock interfaces. 
(d) Investigation of chemical, mineralogical and microstcuctural chacacteristics of reaction zone betwecn cement plug and wall rock.

(c) Analysis of: volume and length changes of grout specumens both in the long-tern exposure scucies and at early age under presisures and tempraturos 5 imulating down hole plug conditions.

(1) Fearibility investigation for developing accelerated aging tochniques by curing specinens at elevated temperatures and/or pressures.

(g) Studieg of the densification of grouts under pressures and somperatures comparable to the expected fiold conditions.

(h) Detarminations of thermal propersies of cement grouts including conductivity and expansion.

The progran will be conducted with appropriate quality controls ...u will be eesponsive to the general quality assurance program.

The rupporting and parallel associated field effort will:

(j) Obtain samples of materials and grout mixtures used for field tests. When possible, obtain samples of grouts during pumping.

(k) Perform tests on materials and proposed grout mixtures using actual cements from cementing contractor's curcent stocks in the Eiel.j lab at the site.

(1) abtain cores of plugs and plug/rock interfaces as required.

(m) Prepare specimens for shipment to the lab for additional testing and inclusion in the long-term exposure and mineralogic/thermodynamic studies.

(n) Implement an effective and practical quality control and quality assucance progran Eor the laboratory testing and supervision of the Eield cementing operations. 


\section{Industrial Assistance}

The need for a cementing industey representative, knowledgeable about available materials, emplacement technlques, and industry capabilities will be qualuated. Slearly, having a cepresentative with hands-on knowledge available as a consultant could preclude possible false ztacts with the field effort and provide asslstance in the development of quality control proceduces.

\section{Plug Design}

Plug design capability will be developed as a part of the materials progzan, with the short-term goal of selecting suitable cementitious plug mixes, performing calculational analysis of candidate designs using material and well bcre in situ properties, and comparing performance to the consequence assesment plug criteria. As this design capability develops, expansion to consideration of the long-term geochemical suitability of cementitious materials and identification of alternate plug materials and designs will occur.

\section{c.2.2. Long Term: Advanced Technology}

1. Geochemical Program

Tor the long-term goals of estahlishing cemintitious material suitability, the development of a tormal geochemical progran will be requiced. While the capabilcy to determine the sui tability and stability of cenentitious materials over geological time perzods may theoretically now exist, an organized, well-defined progran is not available. Estimates of the time to establish a viable program are one to two years, with actual results following this. Hence, this capability is considered a long-rerm goal which can be started now but will not provide answers during the current field test series.

Some representative initial tasks envisioned in the grout suitability portion of the program are listed below. Similar studies relating to natural material candidates will be defined as the program evolves. 
(a) Grout Mineral Phase Analysis

Idontify minerals present in grouts by optical examination of 30 thin: sections by a petrographic microscope and $x$-ray diffraction. Identify zones of chemical reactions taking place during curing. Mapping of selected samples for microprobe quantitative analysis.

(b) Grout Microprobe Analysis

Identification and quantitative chemical analysis of cerent zomponents for characteriation of phases which have and have not reached chemical equilibrium during curing. Depiction of "Erozen" reaction xones and chemical analysis at $70 \mathrm{~A}$ resolution to enable formulation of possible future reactions involving phases in grout and host rack.

(c) Grout and/or Host Rock Thermodynamic Analysis

Calorimetry performed on phases for which basic thermodyanic functions $\left(\mathrm{S}_{0}, \mathrm{~S}_{O}, \mathrm{H}_{\mathrm{O}}\right)$ are not known, so that numerical assessment may be made of reaction potential involving phases is grouts and host rocks, catalyzed by brines.

(d) Grout/Host Rock Reaction Product Analysis

Identification of phases likely to form as a result of postulater reactions involving phases in grout and host rock. Further identification of reaction products likely to have undesicable properties in a grout plug (lower molar volume than ceactants, higher permeability, greater solubility in most probable brine solutions, etc.!

The geochemical program will be carried out under the auspices of ONWI with coordination and design support provided by Sandia, Waterways Experiment 5 tation (NES), and other laboratories as appropriate.

2. Alternate Materials

The use of mon-cementitious materlals as well bore plug andor filter material is necessarily deferred as a future goal of the BHP program 
since a formalized trennology in this field does not exist. The use of natural material os plugs may in the long-term mitigatp the "geologic time" suitability sbjection to grouts, bit the technology to enplacn these materials has not been temonotrated. More appropriately, pernaps, natural materials could be used as fileper or adsorbers of radionuclides if thelz intcoduction to the well borg orcuered. The ultimate ovolution of the plug design could be a composite of cementitious materials as riuid barriers and natural materials as radionuclide harriers, thus providing a multi-media. multi-barcier path t, the biosphere.

Thn alternate materials program is not fully developed at. this time and will be expanded within the ONWI Generic Borehole Progr am. Piovision to incorporate a snall-scale field test of possibin alternate material candidates is included $\mathrm{j} n$ the Field $\mathrm{Tes}$ program ar the Salt Plug Experiment (SPE), and a modest eftort to support the Field Test Program will be conducted by jandia.

\section{c. 3. Instrumentation}

The Fundamental purpose of the instcumentation program is to provide the capability to acquire tho laboratory and figld test data. Proliminary analysis of instrumentation needs and avaliability is described in the tollowing sections.

\section{C.3.L Short-Term Needs}

Near-term necds, by definition, will utilize so-called "off-the-shelf" instruments; those which are available with "cucrent technology." this, of course, does not preclude a measure of adaptation to the constraints of the particular BHP test. In fact, nearly all proposed instruments will denand some modification in the1t specific applications. However, for the near-term, such redesign will be modest. The envisioned applications are riescribed below:

1. Environment. The characterization of borehole conditions and the quantification of the surrounding media will generally utilize 
st ancard wel1-logging apparatus. Howner, in two important areas of mncern, a development effort 15 underway to provide surtable inserimentation as follows:

3. In Situ Stress - The modification of the lacal stresi field by the ar ilizing and subsequent relaxation of the borehole noeds to be surerifined. Through nodeling, in approximation. or the etacturing and increand pornnanility naused by the stress telief san be arteainet. Than, upon emplacament of the plug, any lestoration $y$ the stress field and the consequent healing of tre fractures maj requare monitoring. Sandia is developing nxtensumeters and brensle stress gaçes which may be acceptable for these purposes. These nay be placed eithay in the nain borehole or in nearty zateltite hales.

:. Frasture Delineation - In this case, a reflnement of logging tuols Jod by the oil and gas induatry to determine the fracture content of the host rock is rended. Acoustic techniques may prove valuable in this context.

2. Plug Rssessient. As noted above, the principal focus of the BHP Instruentatior. Program will be to obtain data to cectify the integrity and ourformance of actual emplaced plugs. The near-term offart $w i 1 l$ be keyod to the three field tests planned for FY79 and FY80.

The basic objectives of these tests, beyond gaining field experience in the mechanics of hole preparation and plug emplacement, is to evaluate the quality of the plug. Thus the first demand on the instrunentation is to answer when, where, and how much fluid penetration occurs. The second question is why, and this entails a more sophisticated an iysis, probably culminating in plug renoval by caring. 
Cukront ingtrunentation tochniques under consideration are:

\author{
a. Watis lavel Indicator (in clear holn above plug) \\ b. Electrical conductivity Probe (of fluid abore plug) \\ \&. Finctelcal Resistivity peote (of plidg and tost rock) \\ d. Tracez Detection (gasmus and/oe radioactivo) \\ $\because$ Prossurg and Tempocature (PT) Monitroring (natural or manmalo \\ sesurens) \\ C. Acoustir Protx: (impedance mismatch) \\ 3. Inductance probe fof plug and host rock'
}

Tablo I show: tha estimatgd time scato Eor signifigant events in the drovelopmont of the instrungntation tisted under section $B$.

TABLE II

Near-Term Instrumentation Availability

\begin{tabular}{|c|c|c|c|c|c|}
\hline \multicolumn{2}{|l|}{ Item } & $\begin{array}{l}\text { Design } \\
\text { Phase }\end{array}$ & Fabrication: & Lab Check & Fielding \\
\hline a. & Water Level & $10 / 78$ & $12 / 78$ & $2 / 79$ & $4 / 79$ \\
\hline b. & Fluid Conduci, vity & $20 / 78$ & $12 / 78$ & $2 / 79$ & $4 / 79$ \\
\hline c. & Ptug Resistivity & $9 / 78$ & $10 / 78$ & $12 / 78$ & $3 / 79$ \\
\hline di. & Tracer (gas) & $10 / 7 \mathrm{~B}$ & $12 / 78$ & $2 / 79$ & $4 / 79$ \\
\hline d2. & Tracer (RA/gas) & $3 / 79$ & $6 / 79$ & $9 / 79$ & $12 / 79$ \\
\hline & space resolyed & & & & \\
\hline e. & PT Monitor & $12 / 78$ & $2 / 79$ & $3 / 79$ & $4 / 79$ \\
\hline $\mathrm{F}$. & Acoustic probe & $3 / 79$ & $6 / 79$ & $6 / 79$ & $12 / 79$ \\
\hline g. & Induction Probe & $12 / 78$ & $2 / 79$ & $4 / 79$ & $5 / 79$ \\
\hline
\end{tabular}

A few points are worth noting. Itens $a, b, c$, dl and $e$ will be ready for incorporation into the field test plugs described elsewhere in this program document. Items $d 2$ and $f$ will probably be developed by subcontractors to s[A. The space resolved tracer detection system referred to in d2 involves in conoept a detector able to pinpoint tracer gas leakage paths on a Eractional-inch scale rather than bulk volume sampling as in dl. This system is not available now but the tracer gas canister associated with d2 can be emplaced on $\therefore:=$ dl schedule. The space resolving sensing system is intended for later development. Thus, bulk volume tracer gas detection can be included in the three scheduled field tests. 
3. Laboracory. Filie the major thrust of tha inftrumentation elfort lavolues : Ield activities, more specificaliy quantification of tho plug and its environs, attention must be paid to ancillary activitios. Tre inboratory assessment of mandidate plug material performance wil generally utllize standard apparatus such as iniversal terting machines. One exception to this is:

\section{(a) Test Coll Facility}

Large yolune lligh Pressure Test Sell - A cylindrical chamber sill be i fontified for designed) to accept latge $(0.5 \mathrm{~m}$ diam $\times 1.0$. (ang) cock core samples. The permeability under radial screst: of protstype alugs may the tusted in such an acrangement. Intorfacis and mit-tock fracture conditions are al so accesisible to teat. Develogment of this [actlity is esfontial for nvaluating bonch scaie sarples and initial design will commence in Fy79.

4. Miscellaneous Concerns. This categor includes the Eollowing itomi:

d. Power supplies (possibly remote)

b. Cabling linoluding gas/fluid blocking)

¿ Recording (possibly unattended)

d. Packaging lagainst the down-hole enviroment)

e. Installation (difill stem, wire line, etc.)

f. Calibration, Quality Assurance and Life Testing

With regard to these concerns, the following comments are pertinent:

a. Renote power supplies will not be needed until Table II, items त2, and $t$ are fielded and should be integrated 1 nto thel $t$ design.

b. Cabling capable of withstanding the downhole enviconment will bo emplaced whenever necessary. This type cable is available and routinely used in the oll and gas industry for short in-well bore times sizh as during logging operations but not Eor long-term emplacement as is necessary in the planned fleld tests. Once specific experiment requirements are definet, the cable must be ordered sinse this is a six-month lead time item.

c. Recording Facilities that perinit unattended opozation are in hand* 
d. Packaging requitements are an inherent part of the derign of any downhoie instrument of bensor. Santia will utilizn experience gained in hatsh environnents in other projects such as the in 5 i forsil fuel extraction prograns and at the Nevada jest site,

?. Installation will encall close moperation and coodination with the contract dr $111 \mathrm{ces}$ and with the appropelate finding or gantiations at sandia.

f. Calibration of the sonsor eloments will prored according to ostablished laboratory practice. Life-testing will bo approachor vla magnislcatlons of the anticipated environment. While the $\mathrm{PH}$ requirements: have not heen completely ldentified, all saridia laboratory instriment olibrations are tracoabla utimately to National Durpau of standar ds (NBS), and propec records will bo maintainot.

\section{3.2. Long-Term Needs:}

Long-terin instrumentation development will be oddresised a:; requilement.s ato defined and schodules become firm.

\section{C.4. Field Test Matrix.}

The field program consists of three basic well-bore field tests:

- Bell Canyon Test: (BCT) - A minimum length plug placed to isolate brine water in lower strata (Bell canyon) formations fron the WIPP repository horizon. Existing desp holes near the wIPP site that will be plugged before Einal decommissioning of the WIPp provide the impetus for conducting this test.

- Snallow Hole Test (SHT) - A test to assess the ability of plugs to prevent water flow from water bearing strata above the repository to the salt level. This test wilt be performed in conjunction with nearby mine workings.

- Diagnostic Test Hole (DTH) - A new drill hole through the upper water bearing formations designed to allow detalled diagnosis of individual plugs in a sinçle well bore by using an open centeal casing which permits instruntation access over the full strata range. 


\section{"4.1 Currant Technology Wedl Bore Tests}

in 11 rese: 1 on $n$ : the tentat: ve plan. for this series as well as some

$\because$ ipportang oxperimenta rollows:

i. Br: Canjon Test (OCT)

\section{Canctives:}

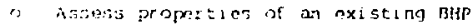

3 a: iesis condition of bormole walls and peripheral region permeability

- Denos:tato capablity for working : n existing industry-like moles

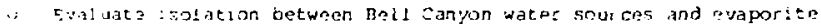

$1, y=2 ;$

Tres isod:

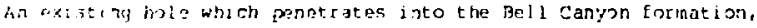
zaiected trom candidato List. (Fiquro l:

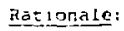

Constrtction of a minimum length cement olug which can withstand the approximately 2000 psi hydrostatic pressure level present in the Bell Canyon Foriration essentially assures that, at least in the short term, zenent pluys can be enplaced to hold off high-pressure hydrostatir: heads. Thus, the isolation of the upper aquifers with head differontials of approximately 200 feet (approximately 90 psi) is eassly within the cureent cement technology capability. This plug $w i l i$ zerve a dual purpose; it is designed to provide a ceal-time seal, thus ploviding data on $i$ ts mechanical plugging capability; it will simultaneously allow confirmation of planned seepage around or through the plug, thereby providing migration rate data for the inderlying brine and tracer gases.

\section{Discussion:}

This test constitutes a worst case scenario for hIPp in terms of a hoscile plug environment (approximately 2000 psi on plug at depth), t isk to the WIPP Horizon in terms of possible dissolutioning, and demonstrates techniques for working at depths on the order of $4000^{\prime}$. Cor ling any existing plug may permit laboratory analysis of bond stcengli, permeability of plug, nature of bond and tcanstion region, aging of plug in situ, and nay lead to conclusions as to the adequacy 
BELL CNNYON TEST (BCT): Establish Capability to Isolate High Pressure zones with Minimum Length Pl:LGs

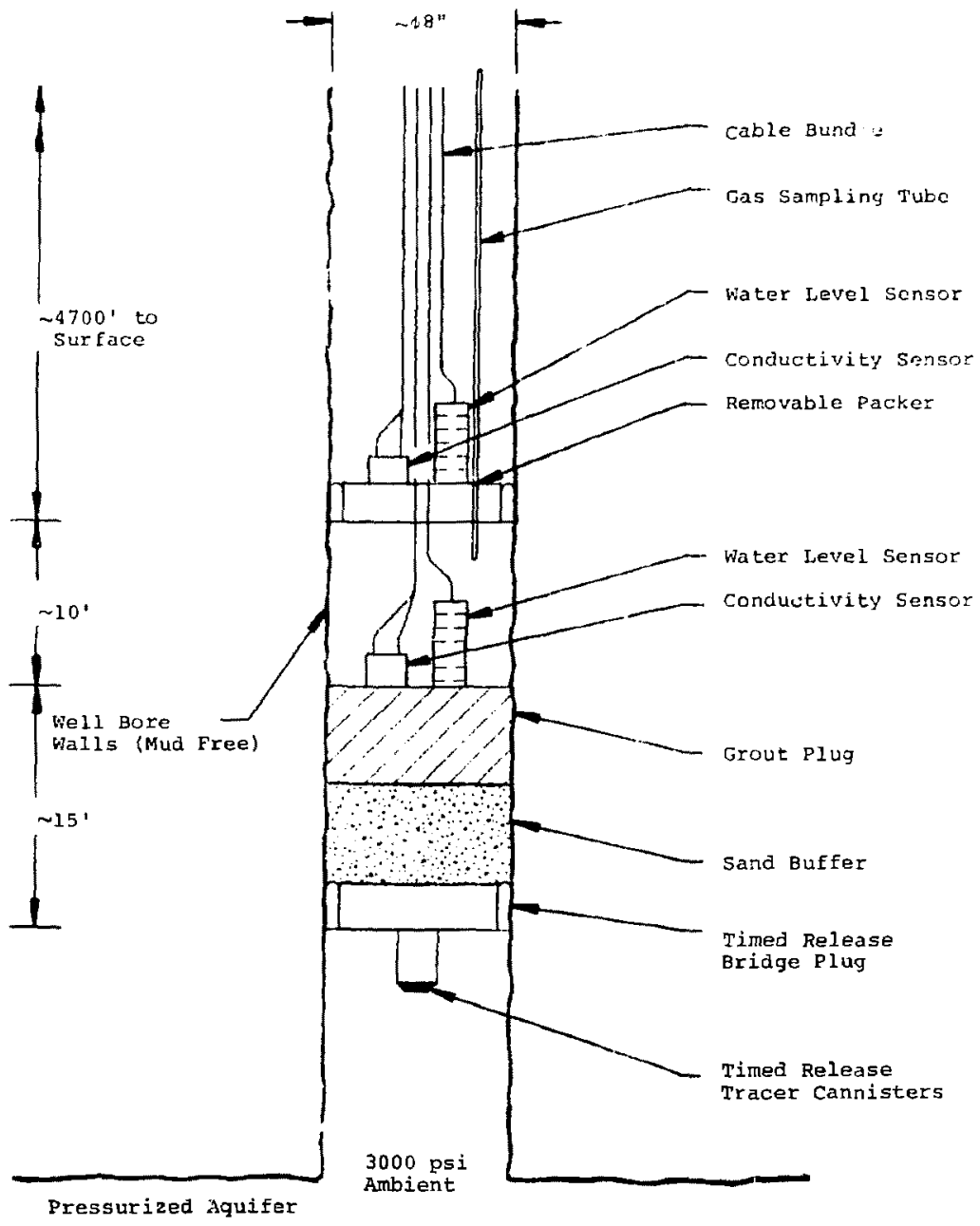


of the technology base when the plug was poured. Emplacing of the copiug wil utilize state-ofme-art cechnology and provise for active ingtrumentation to monitor the plug performance in real time. Successive pluq removal and replugging operations provide the opportunity to certify new plug design technology, to tenove axisting instrumentation penetcations, if required, and providas for permanent. plugging and abandorwent.

The initial plug wll be designed to he of minimum length capabie of withstanding the existing pressure differential. Design will rouiss

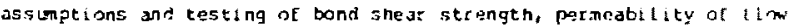
paths at the piug location and calculations of migration times pr comparison to observed times. There will be a seepays tata either around or throigh the plug which is a requirenent for d starcesifu: experiment. The arrival time of the seepage will decorine wluthe: the assumptions are acceptable for a permanent installationi cacly arcival indicating that the leak paths were not adoguateily characterized; late arcival indicating the initial assuptions wer: conser vative.

Planned hardwire instrumentation includns:

l. Monitoring of liquid level at plug top.

2. Monitoring of 1 iquid conductivity at plug top to determine sour of flow, i.e., atther from upper aquifers or from Bell caryon Elow around plug.

3. Tracer gas release at timed intervals below plug will be detected at plug top for determination of migration cates.

There is an I hherent risk in an experiment of this type in that tho design is deliberately selected to be the minimen reguiced to accomplish the objective. Clearly, when overdexigns are permitted, success of the plug is assured in the short term as evidenced by ofl field practices. However, in this test, the gal is to predict che minimun acceptable plug length, install this plug, and monitor the seepage results for comparison to predictions. Due to the deliterats marginal safe design criteria, emplacenent ant casing difficulties arc 
anticipated in the efeots and may have to be repeated. This is part uE the tast and smould not bo construed as a failure. Followmon tests within the woll hore will allow for changes of variables li.e., plug length, material, etc.) to permlt evaluation in onnjunction with the wIPP permahility program of design isolation capobility.

\section{Schcdu IE Impact:}

Minimal schadula impacts - nepd to seloct and acquire toraholo, prepare instrumentation and install. Projected time raguired 6-8 months fron approval to first plug installation.

\section{Information Ancicipated:}

- Well bore preparation and analysis

- Plug emplacement technique

- Quality assurance procedure analysis

D Existing plug integrity assessment

o Mralysis of borenole and perlpheral region permeability

o Assiss plug and formation composite comperence

o Provide samples for laboratory analysis for long-term stability

\section{Conclusions Anticipated:}

succescful stemming of the high pressure ceglan will:

o Permit updating and validation of modeling capability

- Assess the suitability of cement plugs tor withstanding high pe essure source flaws in the short term

o Permit evaluation of the surgical-like plug emplacement techniques requi red. 
2. Snallow Hole Test (SHT)

odectives:

D Anseris ef fectiveness of guerlying aquifer isolation

- Prouida plug/rock samples at salt horizon

3 Provite a tast hed wath accese abrue and below the plug

Trs: Bed:

Existing ur new tole into the salado penetrating a mine working

(Pigurn 2)

Retonale:

Ai miluation of the eftectiveness of coment plugs in isolation flutd

I low will be obtained fran the Bell canyon Test. Using these cesults,

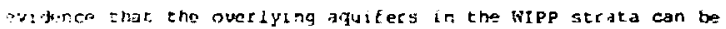

$\therefore$ atal one $\mathrm{Etcm}$ the nther and 3150 from the salt strata will be the

fuli: $\bar{z}$ of this expersiment.

Detailed exparimental dosign is being deferced penóing analysis of stifting plugs. The sutcome of these resilts will be used to

totermino whether or not the shallow Hola Test should bo conducted or combined with the Diagnostic Test kole.

\section{procedure outline:}

(Phose T)

2) Select or drill hole typical sf potash exploration

2) Inspect and tlagnose borehole wall condition and peripheral region permeablity

3) Plug mole with appropriate material and emplace tracers

4) Empiace upper instrumentation

(Phase II)

if Advaice mine to bottom of borehole (perhaps at various lavels)

6) Collect lab samples

7) Emolace tracet gas injection equiment and instrmentation

B) Tracer pressurize plug bottom

9) Monitor upward or downward flow migration

\section{Discussion:}

Utilizing a potash exploration hole provides the opportunity to gain dccess to the borehole bottom Eor additional testing. This borehole 


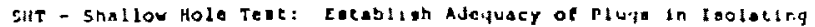
Aquiters

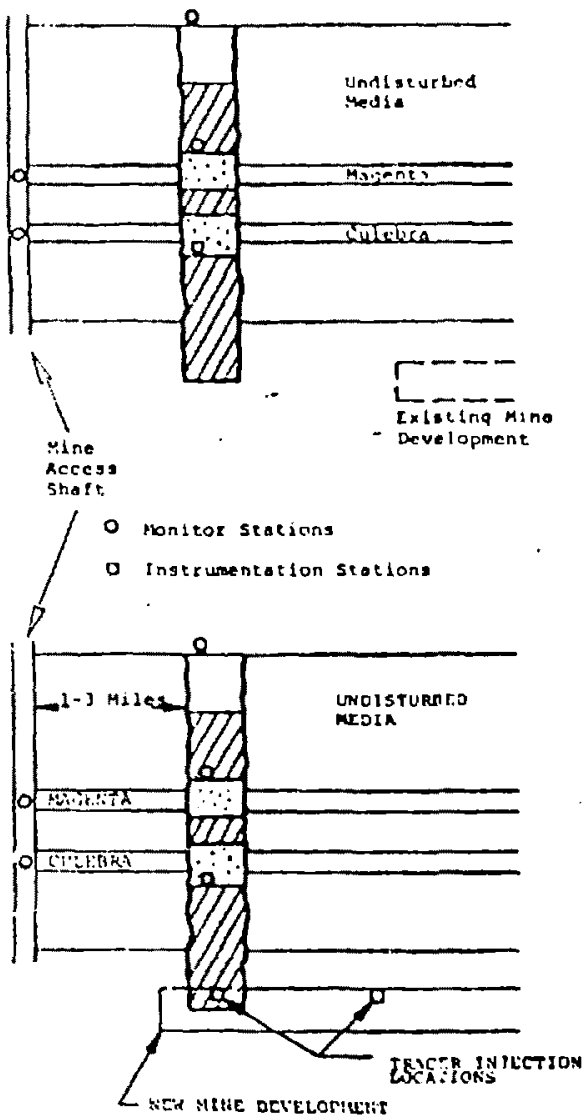

PHASE I

1. Ueldize Exiteing or Dr 111 Potajh Exploraten Hole

2. Plug sale end Aquitero weh bese technigue

3. Inatzument and Mandtor rlow Comand catán

PHASE II

6-12 months arter prase 1

1. Mine back to Dorehole Boteon

2. Conduct Tracer Ingection teste at borehole Bottor and In Und beurbed Mejia. monieor ca Arrival ot Approprlete Locetion le.e.: Accese shafe or at Burtacal

J. Core Pluge Cor Labortisfy Study

- Pemanene he-plug for Abandenment if requires 
will be drilled, instrumenter, piugged, and manitored for Elow communication during phase $t$. During phase $\{I$, (6-12 months) accesis to the plug bottom will be achieved by mining to the plug region where coring and active testing such as tracer gas injection of the plug a.nd native undisturbed media can be done. Laboratory analysis of the pling integrity will be accomplished during this phase. Replugging can be done during this phase if required. As an adjunct, already mined-through existing potash exploration holes can be used to devilop tracer pressuriation techniques and gisancify the technology utilizer? when these plugs were poured.

A decision on whether to conduct the shallow Hole Test will be made when the proliminary results of the Bell Canyon Test are obtained. Clearly, if the BCT is successful in withstanding the high-presiure hear, proof at the lower pressure heads associated with the upper aquifers is redundant. Additionally, this test permits access only it: the top and bottom (salt) strata, with no intermediate strata access. It may be desirable to conduct the Diagnostic Test Hole (DTH) in lieu of the SHT, modified as necessary to achieve the objectives of both expor iments.

\section{Schedule:}

Significant Impact. Acquisition of suitable holes will be depentent: on mine operators acceptance of experiment and agreement to cooperate. Phase II will be tied to mining schedule, and timing of access to plug bottom may be unpredictable. Cost and contract problems are antlcipated.

\section{Information Anticipated:}

- Evaluation of emplacement technique

- Quality assurance procedure analysis

- Analysis of plug and peripheral region permeability

- Assess component plug and upper tormation competence

- Provide samples for laboratory analys;s of long-term effect between plug and host rock 


\section{Dlagnostic Test Hole (DTH;}

\section{Objectives:}

- Provide a full length sample of plug/rock interfaces in upper

\section{formations}

- Provide a test bed for continuous monitoring of in situ plug pertormance

\section{Test Bed:}

P.l1 Supra-Salado rocks (Figure 3)

\section{Rationale:}

Whereas the SHT provides access at the top and botton only of the well-bore, this test permits access at all strata levels, thus providing a more comprehensive test bed facility. The degign of such a test is more complicated than the SHT and requires more preparation time, hut the potential data return is much greater. The Lack of an adequate capabillty to conduct the overcoring operation may preclude the 1 nitial plug installation.

\section{procedure Outline:}

(Phase I)

1) Drill nominal 8" diameter borehole to Salado

2) Inspect and quantify well bore

3) Emplace tracers and instrumentation a.s appropriate

4) Plug hole with best technique and monitor

(Phase II)

1) Overcore plug to $24^{n-36 " ~ d i ~ a m e t e r ~}$

2) Recover samples for laboratory analysis

3) Install new plug with open Iniernal casing

4) Utilize open casing to zonduct on-going plug/peripher al testing at various levels

\section{Discussion:}

This test will provide flexibility within the test program to conduct sample removal, tracer injection, and active monitoring at any selected location in the borehole. The initial phase of this test sequence is to emplace a plug in a new drill hole $\left(8^{n}\right)$ which reaches into the top of the Salado. After sufflcient time for curing and stability, the entire plug would be overcored at a nominal 24 ". The 


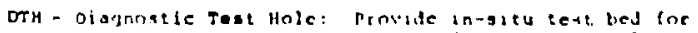

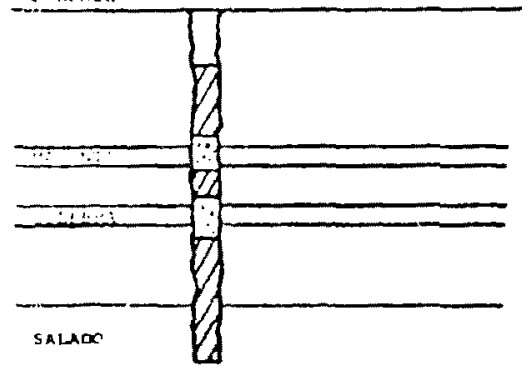

PHASE

1. Defll Nominal e.

Borehole to salado

2. riug with Beat

Techniques

3. Instrument and Monteor ror hqueous iricurelon

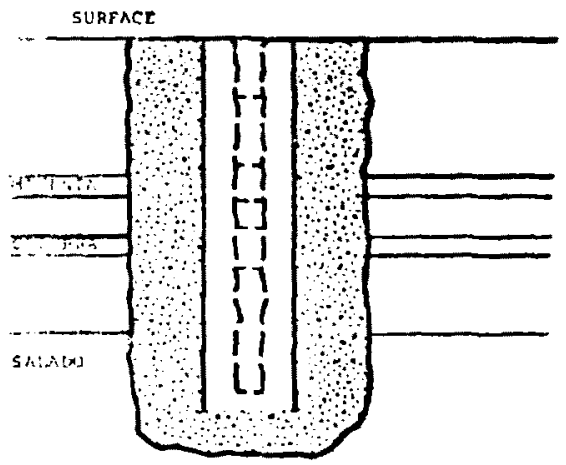

PHASE II

6-12 WOS AFTER PHASE 1 1. Overeore to Plugged Hole

2. Dmplace Plug with Inereral Caling to Provide Diagnoutlc reve fed tor cn-golng Progran

3. Ineerument and konltor 
large plug/rock sample could then be used for laboratory analyais. The second phase would conslst of an appropriate plug in the 24" diameter hole. This plug would also contain a centralized casing (8") which would allow instrumentation access. Future activities would consist of penetcation, tracer injection, pressurization, and instrumentation at selected locations.

The capability to puercore an existing full-length plug may not exist or may be prohibitively expensive, in which case the initial phase nay be deleted and o single $24^{\prime \prime}-36^{n}$ cased hole drilled instead. The experimental impact is the non-availability of the full-length plury, which may be significant. A final decison as to the trade-ofts invo: $d$ in the SHr and DTH will be made at a laier date.

\section{Schedule impact:}

Most signlficant. Complexity of dfilling a new hole and plugging entails considerable cost. Second-phase activities may stress the current over-covering state-of-the-art and add consijerably to overall expenso.

\section{Information Anticipated:}

- Well-bore characterization and data on emplacement tecliniques

- In situ coring and stabilization of emplaced plug

- Provides samples for extensive laboratory analysis of plug, interface and surrounding rock

- Testing and analysis of interactions at any level within flugged region can be conducted over long-term (approximately 20 years) periods. 


\subsubsection{Potential Technology; In-Mine Tests}

The program described thus far relies on current technology to acroinp? ish the Bllp goals. This approach, altmugh likely to be sufficient, is not meant to preclude developing alternate technologies. For this long-term pragram, consideration will be given to the foliowing spocific plenents:

- Alternate Plug Materials.

The Il timate objective in the bHp is to itontify, test, and gual ify appropriate material for use in plugging well bores. Comentituous maierial may ment all the requirements, hut al ter native apprsaches snould he invostigated also. Thus the objective of the alternata plidg matertal developmene is to:

ว. TdentiEY suitable non-cementitious matecial for use on plug materials .

0. Encolurage the design of multilayer, multipurpose plug thaignst ts provide a nul tibarrier egress path.

D. Heslize materials which may behave in identical fashion to the surrounding media and provide additional confidence in long-terra plugging.

- Advanced Instrumentation.

Instrumentation development is recognized as a necessary part of tieid testing, and pcovision for advanced techniques is included in the program to permit development as requized.

To provide for developmental efforts in support of long-term programs, twn fieid enviconment tests are included.

0 Salt Plug Experiment (SPE) - This experiment is designed to provide for in situ testing of alternate matecials for patential application to JHP. Techniques for emplacing and evaluating these materials will be emphasized both in the field and laboratory programs.

- Advanced Instrumentation Develogment (AID) - Space will be provi Jea within the in situ mine environment to permit telcing and development of advanced instrumentation systems for possible future application to the long-term monitoring of bore holg integrtty. 
A discussion of the tentative plan for these two progran elenents foitows:

\section{Salt Plug Experiment (SPE)}

\section{Objectives:}

- Provida for testling and emplacing of altarnata native-like plug materials in salt formations

o Enhance development of long-term alternates to cement.s Test Bed:

A dedicated location in an existlng mine workings

\section{Rationale:}

The development of alternate plugging matartals and emplacement techniques is a long-term goal of the BHP. This experiment provides the initial opportunty to develop this capability with anticlpated extension to a later time well bore plugging test.

\section{Discussion:}

These tests will provide for evaluation of techniques for al ternate plug materials, in the event a nped for such methods is desirable for specific formations in the long-term. Recognizing that native material may represent a viable solution to the eflects of man-made penetrations and that the $\mathbf{s}$ alt hor izon provides the most protection fram the standpoint of repository integrity, it is prudent to establish a program to specifically address plugging salt penetrations with salt. If in fact suitable techniques for emplacing salt or salt-like grouts can be developed which provide adequate isolation, then it can be concluded that the man-made penetrations in the salt. are not weak links in the repository integrity. Existing laboratory analysis (Martin, 1975) indicates that such technique: jaay be available on a laboratory basis, and this experiment will provide for development and testing j.n situ. It represents a Eirst step in the field for addressing a long-term vital alternative in the borehole plugging progran.

\section{Information Anticipated:}

- Salt plug explacement technigue development

o Testing and analysis of in situ salt plugs

- Laboratory salt plug samples for Eurther testing

\section{schedule:}

Comments in MoE schedule apply. 


\section{Advanced Instrumentation Development (AID)}

Objectrues:

- Provide capability for evaluating advanced instrumentation

Test Bed:

h dedicated location in an existing mine workings

RationaLe:

This test will be conducted in conjunction with other ongoing in-mine experiments on a not-to-interfere basis, to provide an in situ test bad for developing instrumentation systems.

\section{Discussion:}

This experiment provides the opportunity to test and evaluate advanced instrumentation equipment and assoc $f^{3}$ ated sensors.

\section{information Anticipated:}

] Performance of advanced systems in in-aitu conditions

- Field experience with șuch systems

Schedule:

Canments in MQE schedule apply.

\section{Summary}

The BHP Program described herein is deslgned to address in a reasonable and scientffic manner the concerns associated with this subject in the past, with the intent of establishing a quantitative data base on borehole plugging techniques. To accomplish this goal, the tests and experiments described atrampt to provide a mix of borehole (with limited access) and inmine (with relativaly unlimited access) enviroments in which assessment of the various issues involved can be undertaken. The end result of the program should lead to a better understanding of which issues are significant and which are not, thereby, permitting emplacement of plugs that satisfy the criteria developed in the progr:ant.

The Bell Canyon Test provides the opportunity to instrunent and analyze a plug in a high pressure region. The Shallow Hole Test permits application of bsst techniques for plugging and then access to both the top and botton of the plug for further analysis. The Diagnostic Test Hole permits recovery of bench scale size samples for analysis and establishes an in-borehole laboratory in wich to conduct testing and analysis in all strata from the surface into the salt horizon. The additional in mine experiments provide the opportuntty to investigate in more detail specific effects on plugs in the salt region and al iows evaluation of instrunentation systens. 
The logic diagran of Flgure 4 is degigned to reflect the overall goals and interconngctions of the varlous aspects of the borehole plugging program. Sita speciflc data pertics piug design modeling and consequence analysis. Following this, Laboratory tosting and cefinements load aventually to fireld tests and in situ data recovery. Succegseul short-term results expand throurh qonchemical techniçuets to evaluate the Iong-tern resuits. Pinally, when bot! short- and long-tern tests have been completed, a sultable plug design is evolved, laading to tine flnal result that fepository isolation can be achiever.

\section{QUALITY ASSURANCE}

A quality assurance program for the WIPP borehole plugging effort will be developed by Sandia Laboratories. This plan will be based on applicable Eeder al rogulations for nuclear installations. Effort will be devoted to categorization of activities so that the appropriate steucture and format is applied to program eloments based on their respective impact on public safety. As requicements specific to waste repositorles are developed, they will be incorporated into the Quality Assurance Plan.

The borehole pluging phase of the WIPP progran will hare a unique relation with respect to quality assurance interface. Although the basic plan will be developed by Sandia, this plan must be compatible ard integrated into both the general WIPP quality assurance plan developed by the wipp project office/DOE and the ONW guality assurance plan. A sijnificant initial pefort on the coordination of these activities will be necessary to expedite the implementation of the $Q A$ Plan and to minimize any deletecsous impact on the technical program. $n$ proposed framework frcm which to bujld an acceptable QA program is shown in Figure 5. 


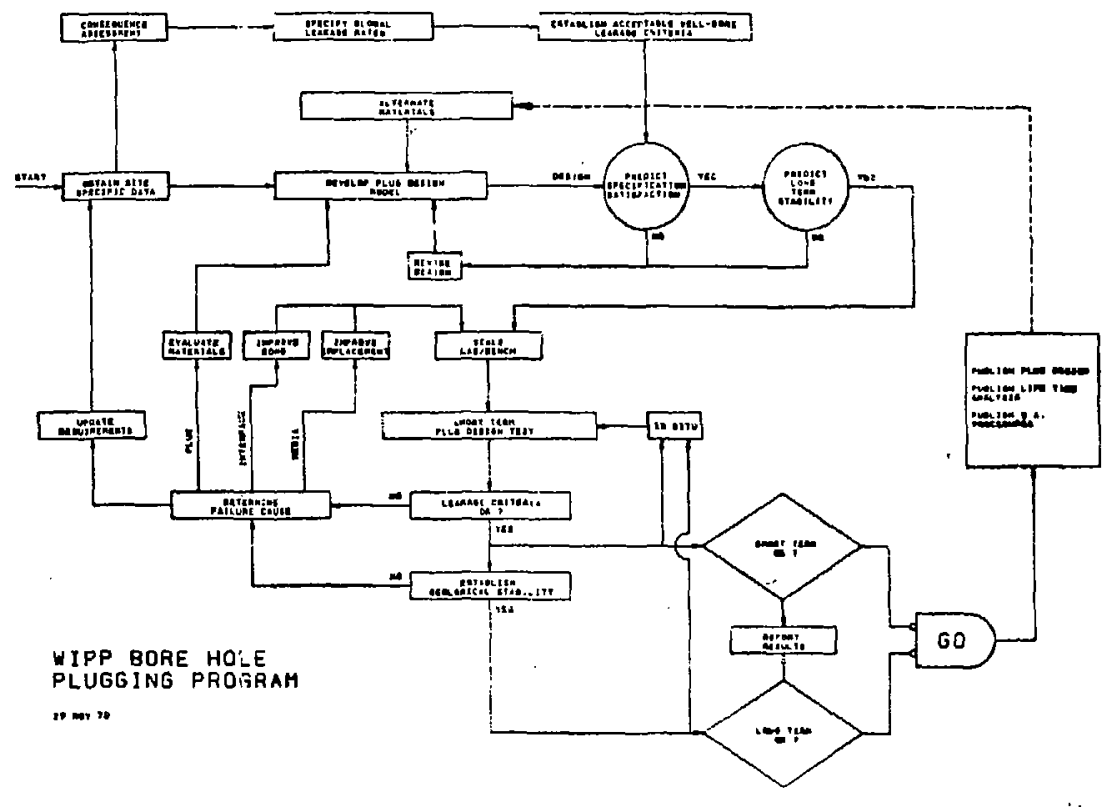


Th instur $=$ that the work done in this progran will gatisfy tequlatory

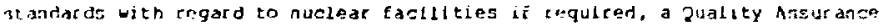
program will he initiated. This program must be conpatible dith the ph plons of both thr wiPP Pcoject offloo (DOE/hPO) and OWWT. To accomplish this,

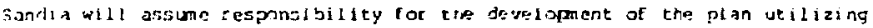
S.andia-selectnd personsel working undor the guidelines set forth by DOE/hTh and any regulatory requicoments. Trancler of the devexopod pijn will be mads

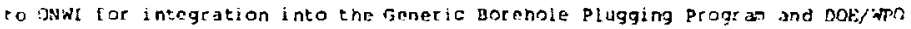
ix integracion tato the operating contcactor's program for wlpP.

The overall responsibllity for the NIPP Bgip QA PLAN will be retaingri by Sandia. Duting t: development of ene plan, interagency liaison will be maintained with al! waste management organizations for appopriate inputs.

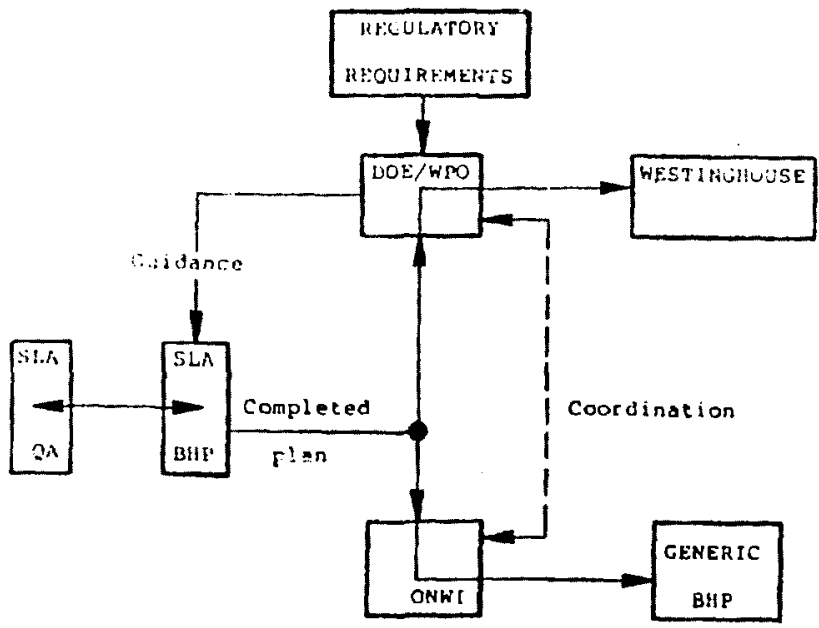

Iigure 5 
AEPOATS

PROGAAM PLAN
DUALITY ASSURANCE PLAH
GROUT MATEATALS
DEVELOPHENI PLAN
INSTRUMENTATIOA PLAN
INSTRUMENTATIOH SYSTEMS
EVALATION PLAN
MONTHLY
TOPICAL

\section{Probaams}

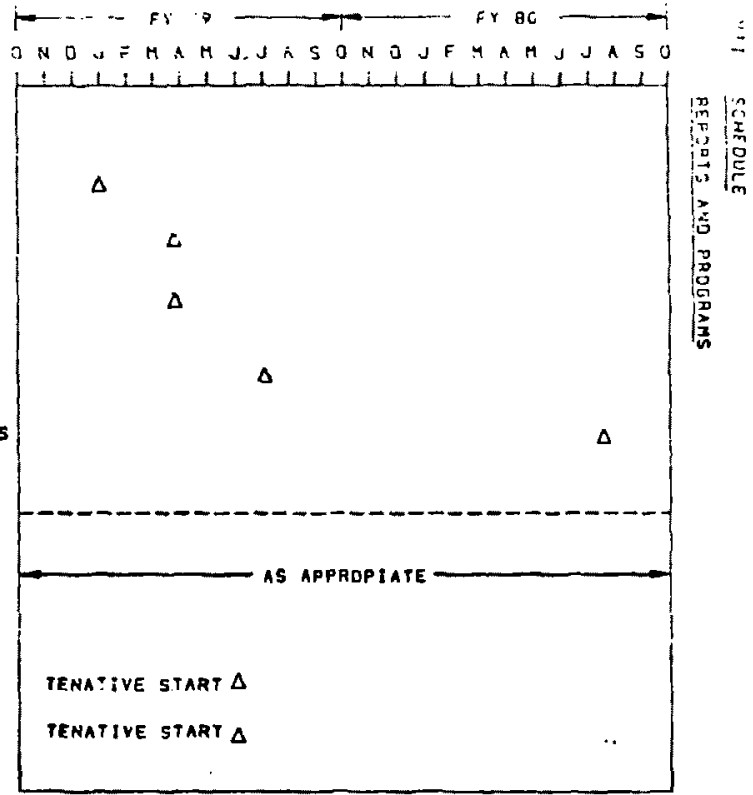




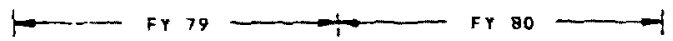

Be11 Canyon Test

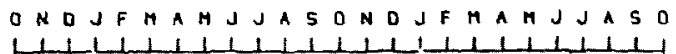

$\pm$

SELECI, COAE, TEST

LABOAATOAY INVESTIGATION

DN TOA

InSTALl PLUG

HONI TOR

he PLUG

$\Delta$

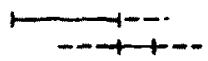

SMALLOY HOLE TEST

EXAHJNE EXISTING PLUGS LABOAATDFY INVESTIUATION

SELECT , COAE, TEST

INSTALL PLUB HONITOR

MINE BACX/TEST

DIAGNUSTIC TEST HOLE

DEF INE, DESIGN

LABOAATORY INVESTIGAFIOH

OA ILL

INGTALL PLUE HOMITOA TEST

MEOIA DUACTFICATTOA EXP.

ADVANCE C INST, OEV.

SALT PLUG EXP. 


\section{Reports}

Reports will be provided in accordance with the Uniform Contractor Reporting System (UCRS) as follows:

\section{Program Plan}

t. Logic Network

Fevel 3 WBS (Subtask Level)

2. Work Breakdown Structure Dictionary

Level 3 was (Subtask Leve1)

3. Hi lestone Log and MileEtone Schedule Plan

4. Cost plan

Leve 12 HgS (Task Level)

5. Manpowes Plan

Leve 12 WBS (Task Level)

\section{Technical Progress Reports}

1. Quarterly

2. Topical

\section{Monthly Status Report}

1. Contract Management Sumary Report

2. Project status Report

3. Cost Managenent Report
A. Level 2 WBS (Task Level)
B. Cost Element

4. Milestone Schedule and Status Report 


\section{WIPP \\ BOREHOLE PLUGGING PROGRAM \\ ORGANIZATION}

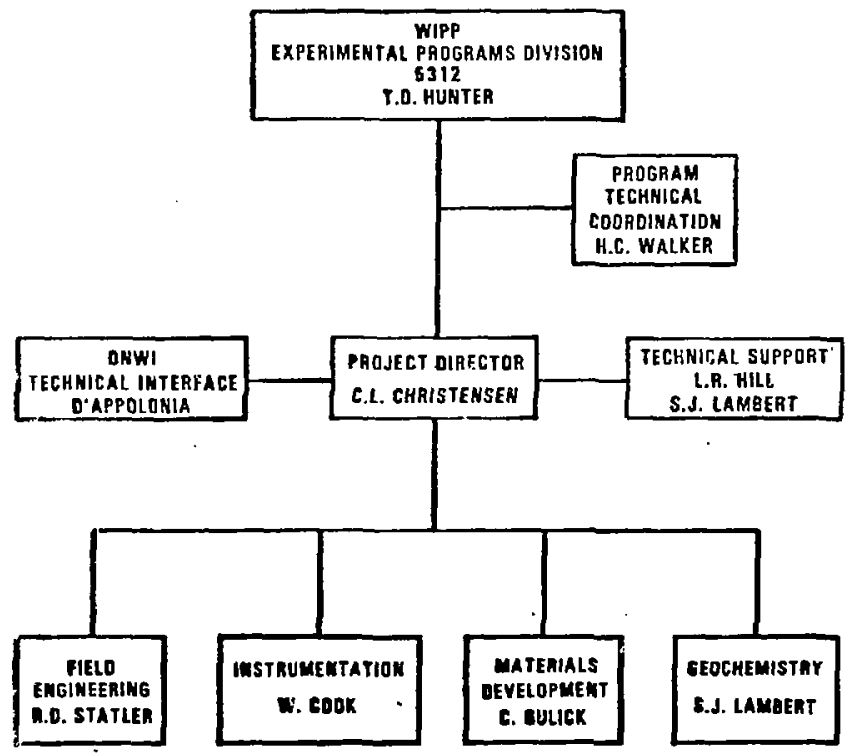

Angust iste

(iin) Sandia Laboraturies 
APPENDI $\mathrm{X}$

$-43=$ 


\section{A. REEERENCES}

Brannen, J. P., 1978. Proliminary safety assessment for wipP as a Repository Draft to be publizhed, Sandia laboratorieg.

Gulick, C. W., Jr., 1979. Borehole Plugjing Materials Develoment Program. sandia Laboratories, Sn:dD78-0715, Unt 1 mited talease.

Martin, R. T. 1975. Feasibility of sealing borenoles with compacted natural eartinn matecial (Vol. I). MIT Research Report 75-28.

Power, D. W., Lambert, S. J., Shaffer, S, E., HiLl, S.. R., reart, W. D. (Editors), 1978. Geological Character iation Report, waste I solation Pilot Plant. (WIPP) Site, Southoastern Now Mexico, Volune I, Sandia Laboratocies, SAND78-1596, Unl inited release. 


\section{BIgCIOGRAPHY}

Battelle, 1978, ONWI Ear ehole Plugging Horkshop, Auguse i77, notes.

Bibliography on Grouting. Miscellanenus Paper c-78-8. Technicalinformation Center and Concrete Laboratory, U.S. Army Engineers waterways Experiment. Station, Vicksburg, MI, Final Report, June, 1978.

Miack, T. L. 1975. Study of borehole plugging in bedded salt dones by earth melting technology. Westinghouse Astronucleat Laboratory. WANL-TME- 2870.

Boa, T, A., Jr., 1978. Borehole plugging progran (waste disposal) report I: Initial inunstigations and preliminary data. Concrete laboratorty, R. S. Army : inginer Haterway Experiment station, Misc. Paper C-78-1.

Branien, J. P. 1978. Preliminary safety Assessment for wipp as a Repositury Draft to be published, Sandia Laboratories.

Dowell, 1973. Borehole sealing. Einal report. Sishcontract 78x-159666 with Unisn Carbi de Corp. Nuclear Div., Oak Ridge, TN.

Eernandez, R., C. MoGown, P. Nolan, R. Morey, and A. Paity 1976. Borehole plugging by compaction process, final report. Draper Laboratory, cambridge, MA. $\quad \mathrm{Y}-\mathrm{OWI}-\mathrm{sub}-7078-\mathrm{L}$.

Gulick, r. W., Jr., 1978. Borehole Pluggfing Materials Development Program. Sandi a Laboratories, SAND78-0715, Unlimited release.

Handbook on the Principles of Hydrology, Hater Information Center. (Donald M. Gray, ed.1. National Research Council of Canada, 1970.

Herndon, J., and 0 . K. Sinith 1976. Plugging wells for abandoriment, $A$ state-of-the-art study and recomended procedures. Hallibucton services. Y/OWT/Sub-76/99068

Idorn, G. M., 1977. Notes from Fall gorehole plugging Meeting in Tucson, 1776. Lea, F. M. 1971. The chemistry of cenent and concrete. Chemical publisning Company, Now Yor k.

Lundberg, L. B. 1975. Advanced borehole plugging by melting. Los Alamos Scientific haboratory.

Martin, R. T. 1975, Feasibility of sealing boreholes with compacted natural earthen material (Vol. I). MIT Research Feport 75-28. 
Roy, D. M., 1975. Bornhole cement and cock properties studies. Progress report. The Materlals Resear oh Iraboranry, The Pennsylvanis stars univrisity. ORNL/SUB $-4031 / 5$.

Roy, D. M., and A. B. White 1375. Borehols plugging by hydrothermal tr ansport. A Feasibility Report Materials Resoarch Labogtory, pennsjlvana State University. Repott to Oak Ridge National Laboratory ORNL/SUR409t/ $\therefore($ May 30,1975$)$.

'ruthild, L. H. 1966, Resistance to chemical attack. ASTM Special Tecnnica: Publication No. 159-A.

halsers, Robert F., 1975. Salt dissolution in oil and gas test holez in Central kansas, Parts $I$ and III. Prepared under Purchase Deder 78x-382B3V. ORvis, Jun 1975.

Weztinghouse. 1976. A systems analysis of instrumention for in situ oxamination of rock properties, Einal report. Hestingnouse Advanced systens Division, NANL-TAE-2B77.

zeiglat, Timothy W., 1976. Detarmination of rock mass parmeability, soils and parement laboratocy, U.S. Army Engineers Waterways Experiment Station, V:cksturg, MJ. 


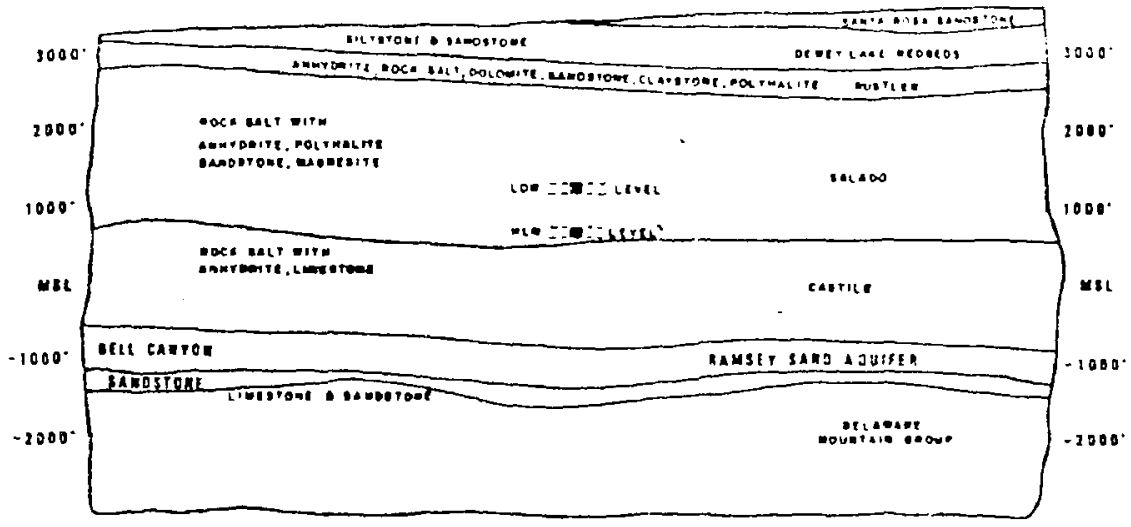

2

a geOlogical section of the los MEDAÑOS area 


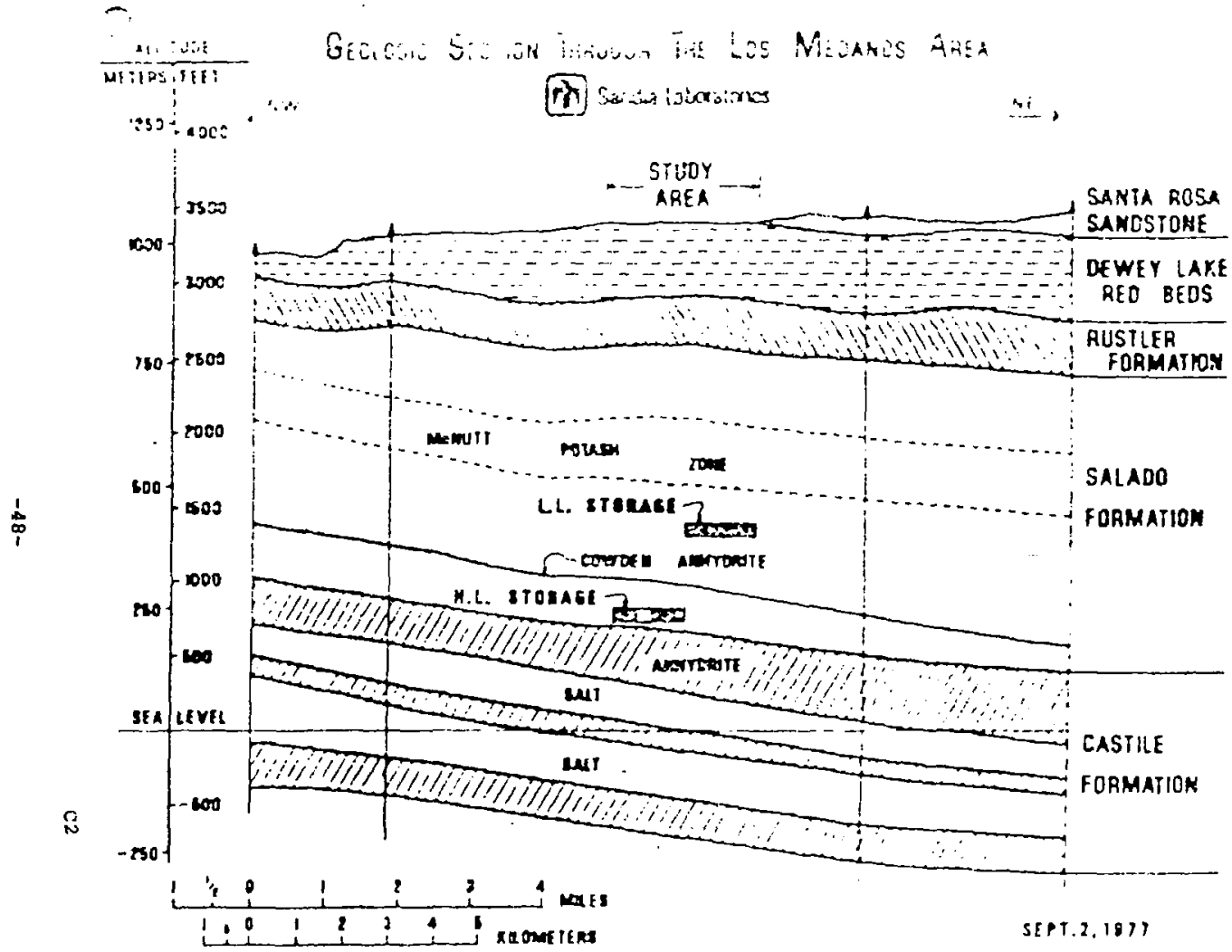




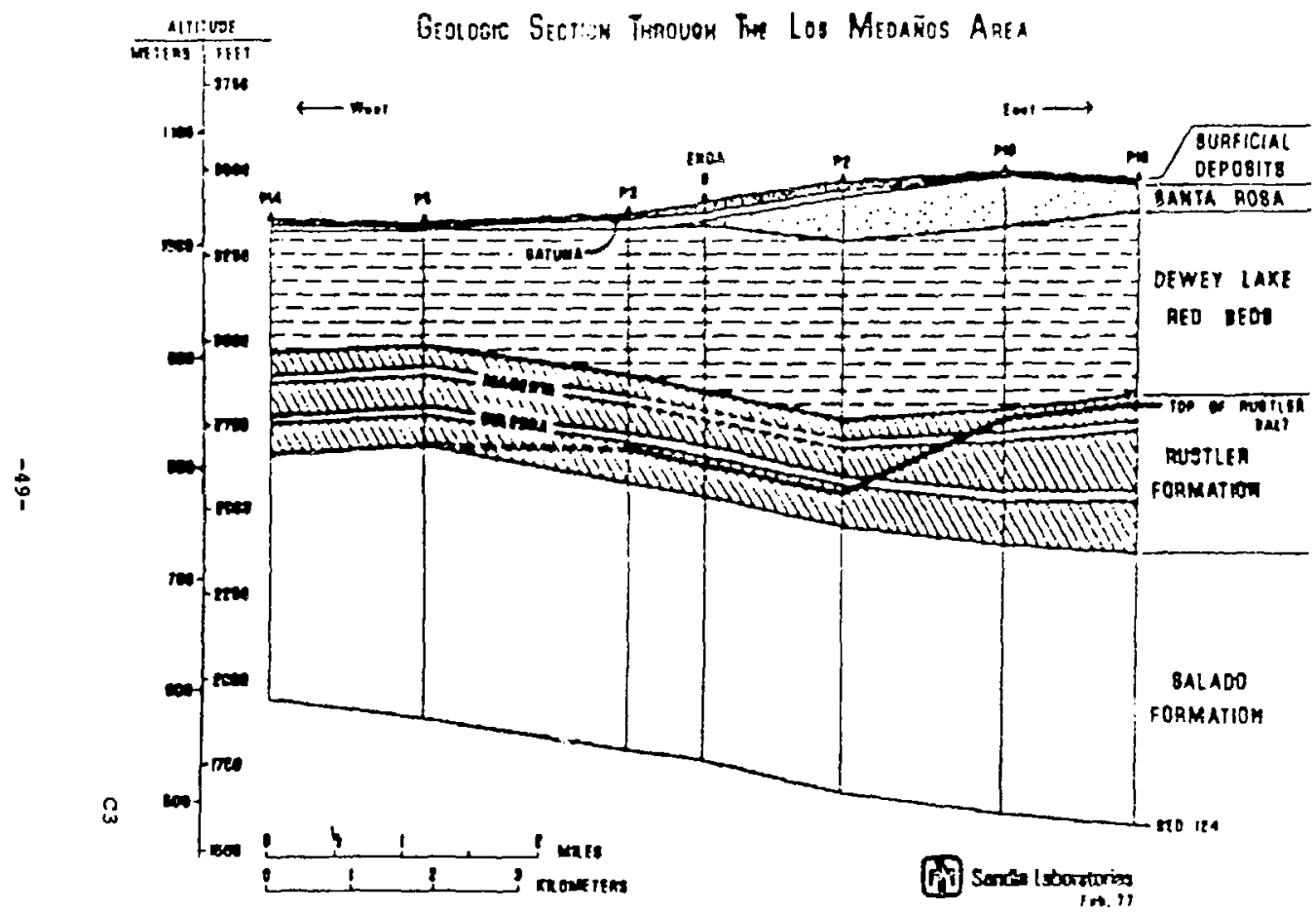




\section{EXPLANATION}

LITHOLOGIC SYMBOLS

\section{sondulone}

Mudsrone; silistone: silty and sondy shole. Shole

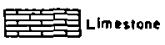

돌ㄹㄹㄹ Dolomise

Charly simestone ond dolomite

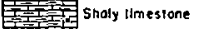

VIIIIIID Anhyorite (ar gyosum?

QIJIJ] Inceriaminaled antyarite-caiclte

Halite (rock solt)

스스스슬 Gronitic rochs

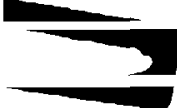

\section{REFERENCES:}

1. Anderson. 1978

2. Angerton, of al, 1972

s. hrokgw. of at . 1972

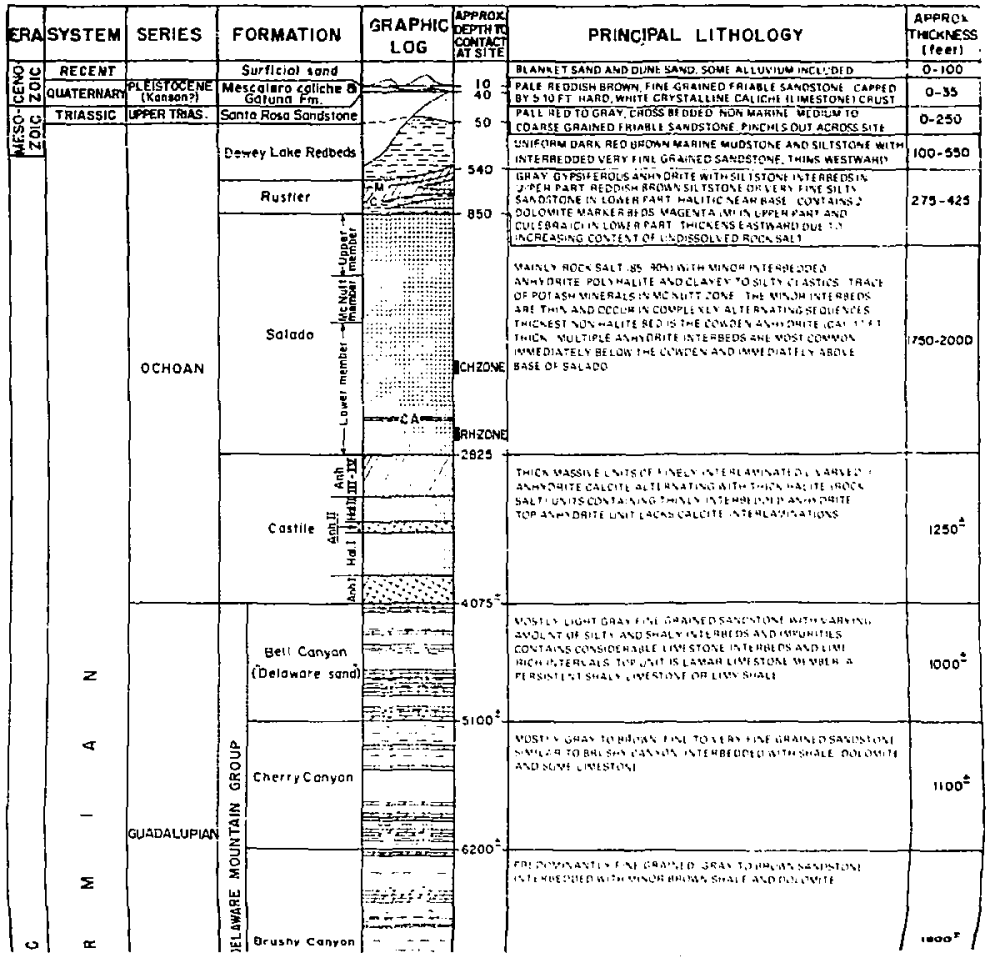


SITE GEOLOGIC COLUMN

C4

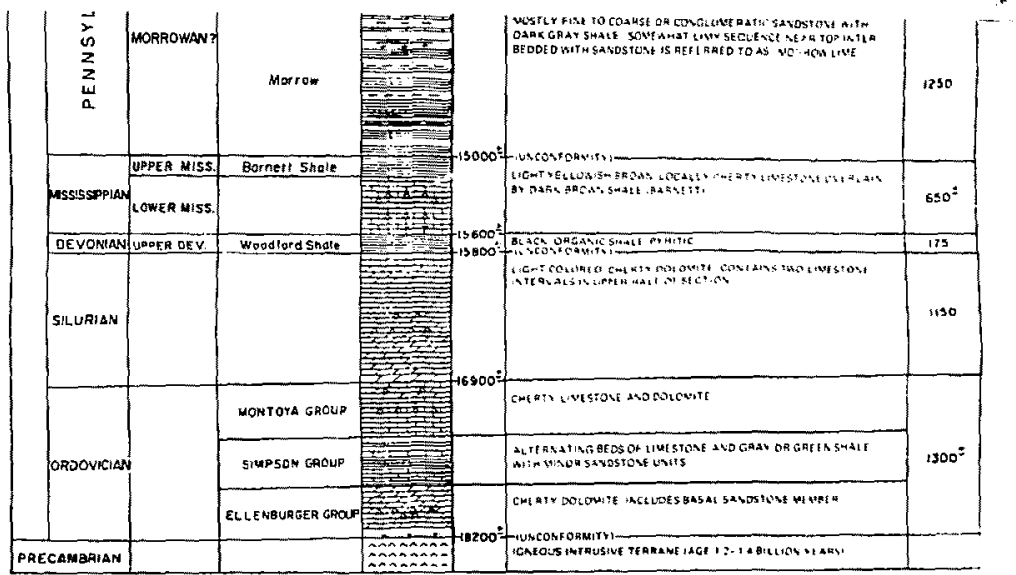

